\title{
Propofol causes neuronal degeneration in neonatal mice and long-term neurocognitive consequences in adult mice
}

\author{
Pei-Xing $\mathrm{Li}^{1}$, Feng $\mathrm{Ru}^{1}$, Yan-Min $\mathrm{Lu}^{2}$ and Lei Zhang ${ }^{1 *}$ \\ ${ }^{1}$ Department of Anesthesia, ${ }^{2}$ Department of Stomatology, Linzi District People's Hospital, Zibo, Shandong 255400, China \\ *For correspondence: Email: zhangleizler@hotmail.com; Tel/Fax: 0086-533-7180469
}

Received: 24 March 2016

Revised accepted: 18 August 2016

\begin{abstract}
Purpose: To investigate the effect of propofol on brain development in neonatal mice and long-term neurocognitive impact in adult mice.

Method: The offspring of female C57BI/6 and male $C D-1$ mice were administered propofol at concentrations of 2.5 and $5.0 \mathrm{mg} / \mathrm{kg}$ (treatment group) or normal saline (control) on postnatal day 7 . Thereafter, histological and immunohistochemical examinations were performed on the mice brain. Apoptotic assay, neuronal nuclei antigen immunohistochemistry (to assess neuron density), and behavioral and neurocognitive tests were conducted on the adult mice.

Results: Propofol induced cellular degeneration and apoptosis in the brains of neonatal mice. It also modulated physiological parameters ( $\mathrm{pH}, \mathrm{PO}_{2}$, glucose and lactate), among which decreased blood glucose might be associated with cellular degeneration in the brain. Propofol also caused long-term neuronal deficits in adults, which showed impaired neurocognitive functions. Upon reaching adulthood, propofol-treated mice showed slow learning response and poor memory compared to controls.

Conclusion: Propofol causes neurodegeneration in neonatal mice and has long-term neurocognitive consequences in adults, indicating that the use of propofol anesthetics in neonates requires careful consideration.
\end{abstract}

Keywords: Anesthesia, Apoptosis, Brain injury, Neonate, Neurodegeneration, Propofol

\begin{abstract}
Tropical Journal of Pharmaceutical Research is indexed by Science Citation Index (SciSearch), Scopus, International Pharmaceutical Abstract, Chemical Abstracts, Embase, Index Copernicus, EBSCO, African Index Medicus, JournalSeek, Journal Citation Reports/Science Edition, Directory of Open Access Journals (DOAJ), African Journal Online, Bioline International, Open-J-Gate and Pharmacy Abstracts
\end{abstract}

\section{INTRODUCTION}

Several classes of anesthetic and sedative agents, such as benzodiazepines, barbiturates, ketamine, propofol, and etomidate, have been used in infants and children. These anesthetics act mainly by blocking $\mathrm{N}$-methyl-D-aspartate (NMDA) receptors and/or enhancing $\mathrm{Y}^{-}$ aminobutyric acid $A$ (GABAA) receptors at various rates [1]. These anesthetic agents have been shown to cause extensive neuronal apoptosis, and neuronal degenerative and morphological changes in neonatal rodents, and subsequent abnormalities in learning and behavior in adults [2-7]. Propofol (chemically, sodium thiopental, or Pentothal) is a commonly used substance for the induction of anesthesia, with more rapid recovery than other anesthetics. It has thus become widely used as an intravenous anesthetic, although it has been shown to induce neurocognitive dysfunction in adults. It has also been reported to induce apoptosis by acting as an NMDA and GABAA agonist and $\mathrm{Na}^{+}$channel blocker $[3,8,9]$. In addition, it impairs cell proliferation and inhibits neurogenesis in the brains of immature mice, possibly also inducing cognitive dysfunction [10].

However, propofol has also been found to play protective roles in hypoxic brains of rats by 
maintaining metabolism, such as lowering arterial blood flow and intracranial pressure [11-13]. It reportedly protects the central nervous system by modulating the intracellular oxidative state through the GABA and NMDA receptors [14-17]. Thus, the roles of such neurotransmitter receptors remain important when considering the use of anesthetics. However, the expression patterns of these neurotransmitter receptors significantly differ in the brains of adults and newborns $[9,18]$ and thus there is significant interest in the cellular mechanisms of general anesthetic agents and their effects on the postnatal development of the brain [19].

In this study, we investigated the effects of propofol administration on the brains of developing mice and elucidated its long-term consequences in adult mice in terms of spontaneous behavior, learning, and memory.

\section{EXPERIMENTAL}

\section{Experimental animals and propofol treatment}

Ethical approval for the animal experiments was obtained from the Institutional Animal Ethical Committee of Linzi District People's Hospital, Zibo, Shandong, China (REF/IAEC/14-15/2198). The protocols for the animal experiments were approved by this committee and conducted in accordance the Guide for the Care and Use of Laboratory Animals, National Research Council (US) Committee for the Update of the Guide for the Care and Use of Laboratory Animals [20]. Female $\mathrm{C} 57 \mathrm{BI} / 6$ and male $\mathrm{CD}-1$ mice were housed under controlled conditions at $22-24{ }^{\circ} \mathrm{C}$ and 50-60\% humidity, with a $12 \mathrm{~h}$ light/dark cycle. The offspring of these mice, on postnatal day 7 (P7), were randomly divided into three groups: normal saline (NS; controls; $n=20$ ), propofol $2.5 \mathrm{mg} / \mathrm{kg}$ body weight (Prop 2.5; $\mathrm{n}=5$, and propofol $5.0 \mathrm{mg} / \mathrm{kg}$ body weight (Prop 5.0; $\mathrm{n}$ $=30)$. All injections were administered intraperitoneally, and then all mice were allowed to develop to adulthood (10 weeks old).

\section{Analysis of respiratory and metabolic factors}

Mice in the control group and Prop 5.0 group $(n=$ 5 , each group) were used to analyze respiratory and metabolic functions at intervals of 3,6 , and $12 \mathrm{~h}$. Temporal profiles were established for the physiological variables, and arterial blood from mice in the anesthesia group was collected at 3, 6 , and $12 \mathrm{~h}$. The blood from the mice was aspirated through the right carotid artery and the levels of $\mathrm{pH}, \mathrm{PCO}_{2}, \mathrm{PO}_{2}$, glucose, and lactate were estimated using an SMARTTM analyzer (iStat Corp., East Windsor, NJ, USA).

\section{Histological examination}

At P7, 12 mice (3 from each group) were exposed to $12 \mathrm{~h}$ of either NS (controls) or propofol (each treatment group). Then they were sacrificed and their brains were excised for histological examination by staining with hematoxylin and eosin (HE). Hippocampal sections of the brain were fixed in $0.1 \%$ methanol, dehydrated, and embedded in wax. These were sliced to $5 \mathrm{~mm}$ thickness and stained with $H \& E$ in the conventional manner. Stained slides were observed under a light microscope (40x) and photographed to examine morphological changes in the CA1 and CA3 regions of the hippocampus.

\section{Immunohistochemistry}

At P7, 12 more mice (3 from each group) were exposed to either NS (controls at interval of $12 \mathrm{~h}$ ) or propofol $(5.0 \mathrm{mg} / \mathrm{kg}$ at intervals of 3,6 , and 12 h). Then they were sacrificed and their brains were excised for immunohistochemical (IHC) analyses of apoptosis. The brains were fixed in 4 $\%$ paraformaldehyde. Then, $40 \mu \mathrm{m}$ sections were cut and blocked on glass slides using $3 \% \mathrm{H}_{2} \mathrm{O}_{2}$. These were incubated with anti-activated caspase-3 (C-3A) antiserum (Cell Signaling Technology, Beverly, MA, USA) at 1:500 dilution. The primary antibody-labeled sections were treated with horseradish peroxidase-labeled antirabbit secondary antibody (Dako, Glostrup, Denmark) followed by visualization using diaminobenzidine chromogen (Dako). Slides were counterstained with hematoxylin, and caspase-3-positive regions were visualized under a light microscope (40x) and photographed. The C-3A-positive cells in brain sections (per $\mathrm{mm}^{2}$ ) were scored; data are presented as the percentage of C-3A-positive cells compared to controls.

\section{TUNEL assay}

The terminal deoxynucleotidyl transferase dUTP nick end labeling (TUNEL) assay is an indicator of cellular apoptosis. The in situ cell death detection kit (Roche Diagnostics, Basel, Switzerland) was used for the TUNEL assay as per the manufacturer's instructions. At P7, 12 more mice ( 3 controls and 5 Prop 5.0 mice) were exposed to $12 \mathrm{~h}$ of NS (controls at interval of 12 h) or propofol $(5.0 \mathrm{mg} / \mathrm{kg}$ at intervals of 3,6 , and $12 \mathrm{~h})$. Then they were sacrificed and their brains were excised for TUNEL staining. Briefly, fixed paraffin-embedded brain tissues were deparaffinized and rehydrated. Then the slides were blocked with $5 \%$ bovine serum albumin and $20 \%$ normal bovine serum in $0.1 \mathrm{M}$ Tris- 
$\mathrm{HCl}, \mathrm{pH}$ 7.5. The sections were washed with phosphate-buffered saline and subjected to end labeling with digoxigenin-11-deoxyuridine triphosphate using the terminal deoxynucleotidyl transferase enzyme. Then the labeled sections were treated with stop-wash buffer and incubated with 4'-6-diamidino-2-phenylindole. The TUNELpositive regions were observed under a light microscope $(40 \times)$ to score TUNEL-positive cells in brain sections (per $\mathrm{mm}^{2}$ ); data are presented as the percentage of positive cells compared to controls.

\section{RNA isolation and quantitative real-time polymerase chain reaction}

Hippocampal slices ( $n=3$, each group) were used for RNA isolation and analysis of the expression of genes involved in apoptotic pathways. Total RNA from brains was isolated using Trizol reagent (Invitrogen, Waltham, MA, USA) and reverse-transcribed to obtain CDNA using the Reverse Transcriptase Superscript III kit (Invitrogen), in accordance with the manufacturer's instructions. Quantitative realtime polymerase chain reaction (qPCR) was performed with TaqMan Universal PCR mix and TaqMan minor groove binder probes labeled with 6 -carboxyfluorescein dye on an ABI 7500 Real Time PCR System (Applied Biosystems, Foster City, CA, USA). The specific primer sets for caspase-3, caspase-9, and PARP genes were used for qPCR. Relative quantification of mRNA was performed by normalizing its level to that of 18s RNA.

\section{Long-term cellular and neurocognitive impact analysis}

The effects of propofol on long-term neurocognition were analyzed in 5 Prop 5.0 mice. After treatment, the animals were kept in chambers and allowed to develop until P28. Then they were separated by sex and placed in different chambers. The neurocognitive tests started at 10 weeks of age, after which the mice were sacrifice; their brains were excised and prepared for neuronal nuclei (NeuN) antigen staining.

\section{NeuN immunohistochemistry}

The NeuN protein is specific to neurons and localized in the nuclei of post-mitotic neurons and perikarya. NeuN IHC staining was performed on the brains of adult mice ( $n=3$, each group) after perfusion with chilled $0.9 \%$ NS and $4 \%$ paraformaldehyde. Paraffin-embedded brain sections $(40 \mu \mathrm{M})$ were rehydrated in graded alcohol followed by washing with Tris-buffered saline Tween-20. Then the sections were incubated with primary NeuN antibody (Chemicon, Billerica, MA, USA) at 1:100 dilution overnight, followed by incubation with donkey anti-mouse IgG secondary antibody (Cell Signaling Technology) for $3 \mathrm{~h}$. The density of NeuN-stained neurons was determined using a laser-scanning confocal microscope (Nikon, Tokyo, Japan). NeuN-stained neurons were examined in the CA3 pyramidal cell layer of the hippocampus and retrosplenial cortex regions adjacent to the brain midline. The data are quantitatively expressed as raw neuronal density counts and percentage NeuN expression, for comparison between the propofol-treated and control groups.

\section{Behavioral observations and neurocognitive testing}

The Morris Water Maze (MWM) test has been widely used to analyze spatial learning and memory in behavioral neuroscience, as described elsewhere [21]. Prior to this test, offspring were kept together in groups from the same dam up to P28. For the MWM test, a pool $(100 \mathrm{~cm}$ diameter $\times 50 \mathrm{~cm}$ depth) with black internal coating was filled with water $\left(27^{\circ} \mathrm{C}\right)$ and a camera was placed $2.5 \mathrm{~m}$ above it. The pool was divided into four quadrants: northwest (NW), northeast (NE), southwest (SW), and southeast (SE). Spatial learning was examined using an escape platform (10 $\mathrm{cm}$ diameter) placed in the second quadrant (submerged at a depth of $2 \mathrm{~cm}$; $25 \mathrm{~cm}$ from the edge). Mice were allowed to find the location of the platform by training four times per day on four successive days. Latency time represents the spatial learning ability in terms of finding the hidden platform from the start position (in the SE quadrant). A probe trial was performed to test spatial memory, starting from the start position on day 5 in a platform-less pool. The time of the first crossing of the site where the platform had previously been located and the frequency of such crossings were recorded.

\section{Statistical analysis}

Data are presented as mean \pm standard deviation (SD), unless specified otherwise. Data were compared among groups using one-way analysis of variance (ANOVA) with Tukey's post hoc tests for multiple comparisons. MWM test data were analyzed using two-way ANOVA for repeated measurements at different time points. The qPCR gene expression analysis was analyzed by Student's $t$ test. All statistical calculations were performed using SPSS v.17, and $p<0.05$ was considered statistically significant. 


\section{RESULTS}

Effects of propofol on morphological
structures in the brains of neonatal mice

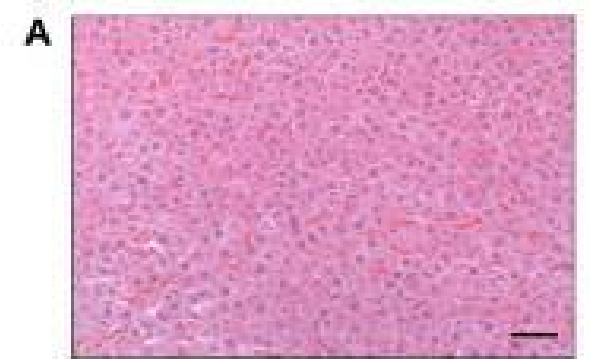

B

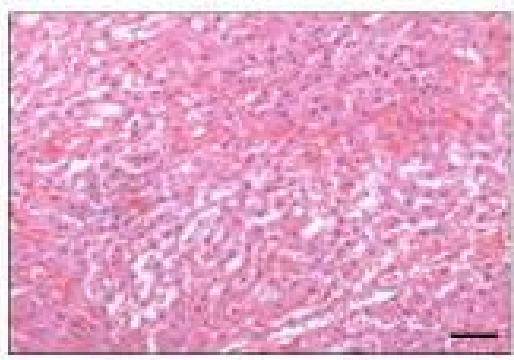

C

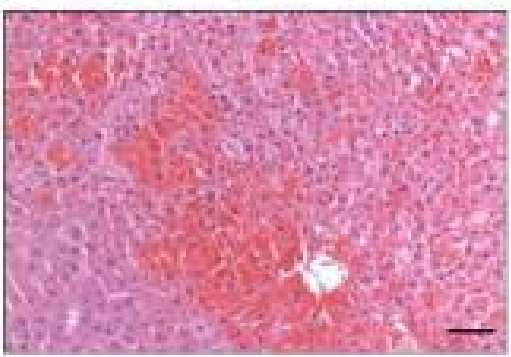

Figure 1: Effects of propofol on the neonatal mouse brain. Hematoxylin and eosin-stained brain cortex slices from neonatal mice treated with propofol for 12 h were analyzed under a light microscope (40x). A) control group; B) $2.5 \mathrm{mg} / \mathrm{kg}$ propofol; C) $5.0 \mathrm{mg} / \mathrm{kg}$ propofol; $\mathrm{n}=3$; scale bar $=100 \mu \mathrm{M}$

Histological staining of brain slices was performed $12 \mathrm{~h}$ after NS or propofol exposure. Propofol treatment caused swelling of the pyramidal neurons in the CA1 region of the hippocampus in a dose-dependent manner (Figure 1). Cellular clumping and degenerative patches became prominent and the nuclei were dark and shrunken compared to controls. The degenerative effects of propofol on the morphology of brain segments also increased in a dose-dependent manner. Prop 5.0 mice showed more drastic changes in brain morphology, as shown by the orange-red patchy areas in Figure 1C, than Prop 2.5 mice. Based on these results, Prop 5.0 mice were used for further experimental analyses using different exposure times of anesthetic (3, 6, and $12 \mathrm{~h}$ ). The $12 \mathrm{~h}$ exposure group was selected for further studies.

\section{Propofol affects respiratory and metabolic factors in neonatal mice}

Propofol exposure caused respiratory and metabolic imbalances in the neonatal mice, indicating its critical effects on early brain development (neurogenesis) as neurons are both produced in excess and also eliminated quickly during this critical stage of development. After 12 $\mathrm{h}$ of propofol exposure, $\mathrm{pH}$ was significantly reduced compared to controls. $\mathrm{O}_{2}$ pressure was also significantly reduced, but $\mathrm{CO}_{2}$ pressure did not show a statistically significant change. Glucose level was significantly lower after $12 \mathrm{~h}$ of propofol treatment compared to controls, while lactate level was significantly higher at $12 \mathrm{~h}$. These results indicate that propofol administration caused metabolic acidosis, as demonstrated by reduced $\mathrm{pH}$, and modulated the levels of blood glucose and lactate (Table 1).

\section{Propofol induces cellular degeneration in the brains of neonatal mice}

Cellular degeneration in terms of cell death was measured using the apoptotic TUNEL assay, followed by C-3A IHC. TUNEL staining (Figure 2A, C) data showed significantly increased staining in hippocampal (CA1 and CA3) regions in Prop 5.0 mice compared to controls, and there was a time-dependent increase in apoptosis in the brain: $6 \%, 14 \%$, and $22 \%$ at 3, 6, and $12 \mathrm{~h}$ after exposure, respectively (Figure 2C). Control mice showed no apoptotic staining.

Table 1: Physiological factors in neonatal mice

\begin{tabular}{lccccc}
\hline Parameter & \multicolumn{2}{c}{ Control $(\mathbf{n}=5)$} & \multicolumn{3}{c}{ Propofol $(\boldsymbol{n}=\mathbf{5})$} \\
\cline { 2 - 6 } & $\mathbf{0} \boldsymbol{h}$ & $\mathbf{1 2} \boldsymbol{h}$ & $\mathbf{3} \boldsymbol{h}$ & $\mathbf{6} \boldsymbol{h}$ & $\mathbf{1 2} \boldsymbol{h}$ \\
\hline $\mathrm{pH}$ & $7.36 \pm 0.03$ & $7.28 \pm 0.04$ & $7.31 \pm 0.02$ & $7.21 \pm 0.03$ & $7.08 \pm 0.02^{*}$ \\
$\mathrm{PCO}_{2}(\mathrm{mmHg})$ & $54 \pm 7$ & $50 \pm 6$ & $48 \pm 4$ & $51 \pm 5$ & $55 \pm 5$ \\
$\mathrm{PO}_{2}(\mathrm{mmHg})$ & $146 \pm 4$ & $141 \pm 3$ & $144 \pm 5$ & $128 \pm 4$ & $116 \pm 3^{*}$ \\
Glucose $(\mathrm{mg} / \mathrm{dL})$ & $134 \pm 8$ & $108 \pm 6$ & $114 \pm 6$ & $96 \pm 7$ & $82 \pm 5^{*}$ \\
Lactate $(\mathrm{mmol} / \mathrm{L})$ & $2.8 \pm 0.3$ & $3.6 \pm 0.4$ & $4.8 \pm 0.4$ & $5.4 \pm 0.5$ & $6.2 \pm 0.5^{*}$ \\
\hline
\end{tabular}

Values are presented as mean \pm standard deviation; ${ }^{*} p<0.05$ vs. control at $12 \mathrm{~h}$ 
These results were supported by the results of $\mathrm{IHC}$ staining of C-3A in cortical sections (Figure 2D-F). Hippocampal sections of controls showed almost no staining, while Prop 5.0 mice showed increased staining in a time-dependent manner: $4 \%, 10 \%$, and $16 \%$ at 3,6 , and $12 \mathrm{~h}$ after propofol treatment, respectively (Figure $2 \mathrm{~F}$ ).

\section{Propofol induces apoptosis in the brains of} neonatal mice

Propofol-induced neurodegeneration was further confirmed by analyzing the expression of the apoptosis-related genes caspase- 3 and PARP (Figure 3 ). Propofol exposure caused a time- dependent increase in caspase-3 mRNA levels. Specifically, it caused 1.2-, 1.4-, and 1.6-fold increases in caspase-3 levels at 3,6, and $12 \mathrm{~h}$ after exposure. Comparing the gene expression data to those in the $12 \mathrm{~h}$ control, propofol increased caspase- 3 mRNA levels by 1.3 -fold ( $p$ $<0.05)$ and 1.8 -fold $(p<0.04)$ at 6 and $12 \mathrm{~h}$, respectively. Similarly, it caused time-dependent increases in PARP by 1.2-, 1.4-, and 1.6-fold at 3,6 , and $12 \mathrm{~h}$. The PARP expression data showed statistically significant differences at 6 and $12 \mathrm{~h}(p<0.05$ and $p<0.04)$. The increases in caspase- 3 and PARP mRNA levels confirm the induction of apoptosis in hippocampal slices via activation of the apoptotic pathway.
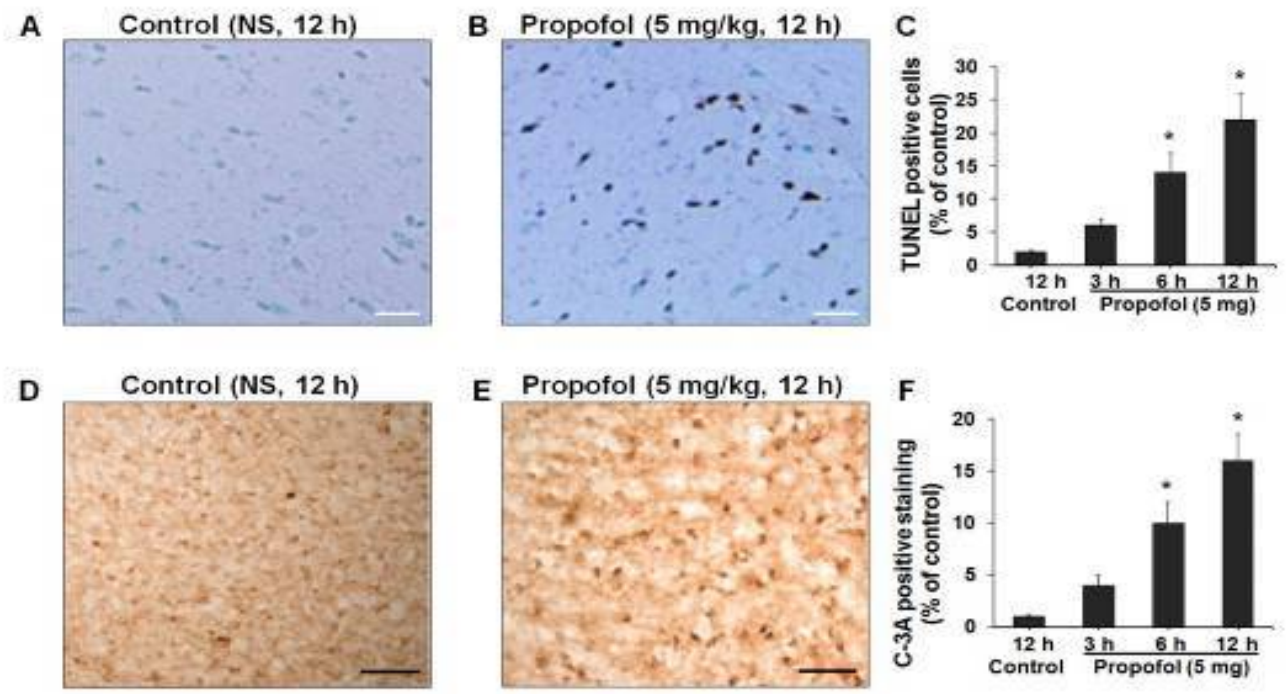

Figure 2: Effects of propofol on apoptotic cell death in brain cortical sections. A-C, TUNEL staining for apoptosis and quantitative expression analysis data. D-F, IHC staining for activated caspase- 3 and quantitative expression analysis data. $\mathrm{n}=3$; scale bar $100 \mu \mathrm{M}$. * $p<0.05$ vs. control
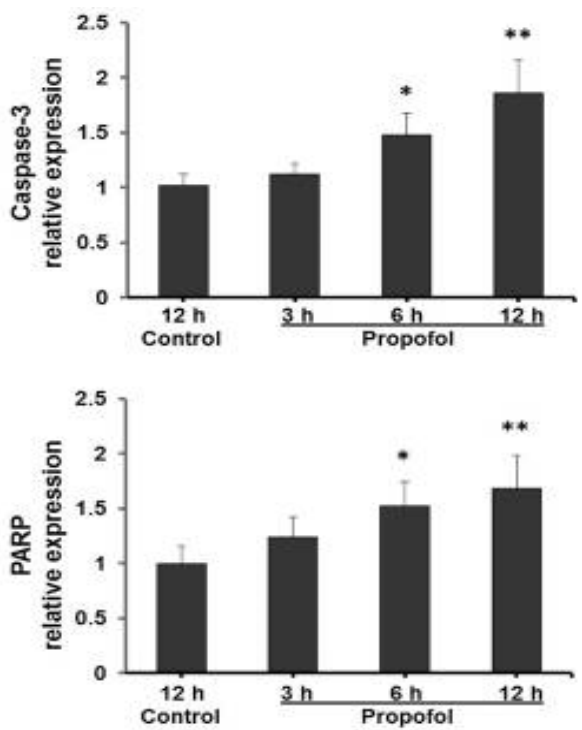

Figure 3: Quantitative real-time polymerase chain reaction analysis of the apoptosis-related genes caspase-3 and PARP in hippocampal slices; $\mathrm{n}=3$; ${ }^{*} p$ $<0.05 ;{ }^{* *} p<0.04$
Effects of propofol on long-term cellular and neurocognitive functions in mice

The hippocampal CA2/3 and cortical sections of the brains of adult ( 10 weeks old) mice indicated vigorous cell loss in mice that were treated with propofol as neonates (Figure 4). NeuN expression in control mice demonstrated the presence of healthy neurons (Figure 4A), while decreased NeuN positivity in postembryonic propofol-treated mice indicated the degeneration of differentiated neurons (Figure 4B). The reduced NeuN expression ( $4 \%$ ) compared to controls $(\sim 15 \%)$ indicates altered functional and morphological developmental in the neurons of treated mice.

\section{Effects of propofol on behavior and learning of mice}

In terms of learning behavior, the latency time 


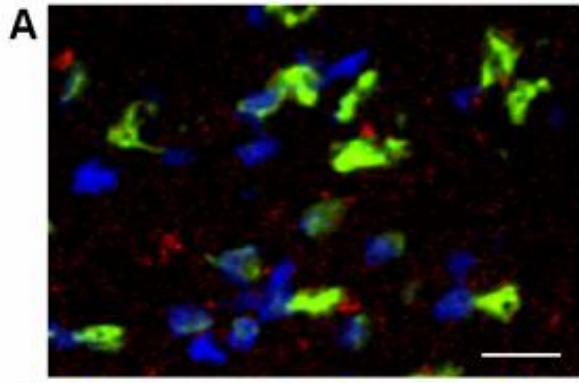

B

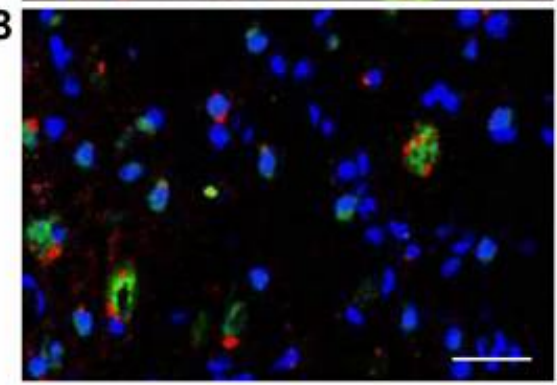

Figure 4: Neuronal nuclear antigen (NeuN) expression pattern in cortical brain sections of adult mice (10 weeks old). A) control group; B) propofoltreated group; C) NeuN expression quantification. $\mathrm{n}=$ 3; scale bar, $200 \mu \mathrm{M}$; ${ }^{*} p<0.05$ vs. control

data showed a tendency for decreased latency from day 1 to day 4 in both controls and propofoltreated mice (Figure 5). This trend in control mice is an indicator of normal learning. Control mice showed a latency time of $99.4 \pm 8.6 \mathrm{~s}$ on day 1 , which gradually shortened to $61.4 \pm 8.2 \mathrm{~s}$ on day 4. Propofol-treated mice showed almost the same latency time on day $1(102.7 \pm 9.4 \mathrm{~s})$, but on day 4 it was noticeably and significantly longer $(76.8 \pm 8.6 \mathrm{~s})$ than in controls. The latency times of propofol-treated mice on days 2,3 , and 4 were significantly longer than in controls $(p<$ $0.05)$. Propofol treatment caused an increase in their latency time, reflecting a slow learning response compared to controls.

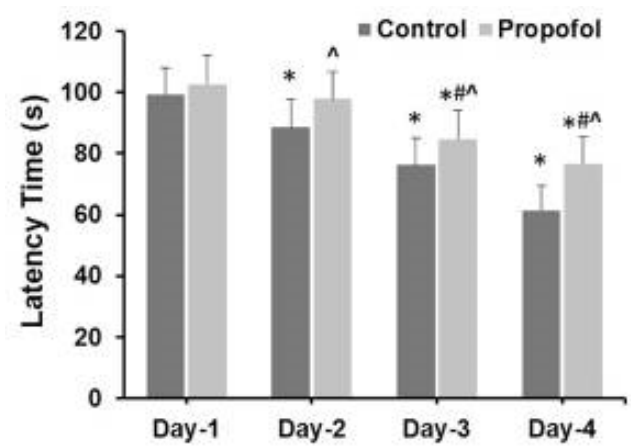

Figure 5: Effects of propofol exposure on the learning behavior of mice analyzed by latency time (s) scoring. $\mathrm{n}=3 ;{ }^{*} p<0.05$ vs. control day $1 ;{ }^{*} p<0.05$ vs. propofol day $1 ;{ }^{\wedge} p<0.05$ vs. control on the same day
Next, we analyzed the effects of propofol on the time of first crossing of the site where a submerged platform had previously been located and the frequency of such crossings in a pool. The values in the control group were $42.26 \pm$ $11.6 \mathrm{~s}$ and $2.2 \pm 0.92$ times, respectively, and those in the treated mice were $58.62 \pm 12.4 \mathrm{~s}$ and $1.4 \pm 0.62$ times, respectively $(p<0.03)$. The frequency of crossings was marginally significantly different $(p=0.048)$ between the propofol-treated group and the control group.

\section{DISCUSSION}

The effect of propofol exposure on neuronal growth and brain development in neonatal mice was evaluated by analyzing its subsequent impacts on learning and memory functions in adulthood. Propofol caused neurodegeneration and induced neuronal apoptosis with degenerative signs in mature neurons in adult mice, which exhibited poor learning and memory behavior. Our findings suggest that propofol alone may not be a suitable anesthetic in clinical and surgical procedures for neonates.

Certain adverse effects of anesthetics have been reported, such as the induction of neurodegeneration within several hours of exposure in neonates and impairment of neurocognitive performance in adulthood. The administration of anesthetics and sedative agents in rodents during synaptogenesis has been shown to have marked degenerative effects [2-7] associated with long-term neurocognitive deficits. The present study demonstrates that propofol caused cellular degeneration and led to long-term neuronal deficits in adulthood. Propofol exposure in neonatal mice induced degenerative signs, swelling of pyramidal neurons in the CA1 region of the hippocampus, cellular damage, and degenerative structural changes in brain sections. It also caused cellular degeneration in the brain and modulated the levels of physiological parameters $\left(\mathrm{pH}, \mathrm{PO}_{2}\right.$, glucose, and lactate). However, the exact mechanisms behind anesthetic-induced neurotoxicity and damage to the neuronal signaling pathways remain unclear. Nonetheless, apoptotic modulation is identified as the main mechanism of anesthetic-mediated cellular responses, which further correlates with the activation of many cellular signaling components such as cell death signals, cleavage of cytoskeletal proteins, signaling kinases, and DNA repair enzymes in neuronal as well as nonneuronal cells $[3,8-10,12,22,23]$. In this study, the activation of caspase-3, ultrastructural changes in the brain, and TUNEL and NeuN staining reflected the impacts of propofol on the brains of neonatal mice, causing neurotoxicity at 
a critical developmental stage that led to longtern neurocognitive impacts on adult mice. C-3A IHC staining data confirmed these results.

Anesthetics in general or at least at an excessive dose may have long-term effects on the developing brain and subsequent cognitive function, which must be taken into consideration when treating pediatric patients. Several anesthetics, including ketamine, midazolam, isoflurane, and propofol, have been reported to cause neurodegeneration in the developing brain and subsequent cognitive dysfunction in several animal models $[2-7,10]$. Propofol has also been reported to cause neuroapoptosis in the developing brain at clinically relevant concentrations and durations, leading to neurocognitive dysfunction [24,25]. In terms of the impact of propofol on long-term cellular and neurocognitive functions in neonatal mice, we found vigorous cell loss and hindered cognitive performance in propofol-treated mice in adulthood compared to controls.

We propose that propofol may inhibit amino acid neurotransmitters such as aspartate, glutamate, glycine, and GABAA, because these neurotransmitters play a central role in developmental morphogenetic processes in the brain.

\section{CONCLUSION}

Propofol exposure causes neurodegeneration in the brains of neonatal mice, leading to learning and behavioral deficits in adults. Its effects may be due to the lowering of blood glucose levels as well as the release of amino acid neurotransmitters. Overall, our findings indicate the need for careful consideration prior to the use of propofol in surgical procedures in neonates.

\section{DECLARATIONS}

\section{Acknowledgement}

The authors are grateful to the Department of Anesthesia and the Department of Stomatology, Linzi District People's Hospital, Zibo, Shandong, China, for providing support for this study.

\section{Conflict of Interest}

No conflict of interest associated with this work.

\section{Contribution of Authors}

The authors declare that this work was done by the authors named in this article and all liabilities pertaining to claims relating to the content of this article will be borne by them.

\section{REFERENCES}

1. Campagna JA, Miller KW, Forman SA. Mechanisms of actions of inhaled anesthetics. N Engl J Med 2003; 348: 2110-2124

2. Fredriksson A, Archer T, Alm H, Gordh T, Eriksson P. Neurofunctional deficits and potentiated apoptosis by neonatal NMDA antagonist administration. Behav Brain Res 2004; 153: 367-376.

3. Jevtovic-Todorovic $V$, Hartman RE, Izumi $Y$, Benshoff ND, Dikranian K, Zorumski CF, Olney JW, Wozniak DF. Early exposure to common anesthetic agents causes widespread neurodegeneration in the developing rat brain and persistent learning deficits. J Neurosci 2003; 23: 876-882.

4. Young C, Jevtovic-Todorovic V, Qin YQ, Tenkova T, Wang $H$, Labruyere J, Olney JW. Potential of ketamine and midazolam, individually or in combination, to induce apoptotic neurodegeneration in the infant mouse brain. Br J Pharmacol 2005; 146: 189-197.

5. Liu JR, Liu Q, Li J, Baek C, Han XH, Athiraman U, Soriano SG. Noxious stimulation attenuates ketamineinduced neuroapoptosis in the developing rat brain. Anesthesiology 2012; 117: 64-71.

6. Loepke AW, Istaphanous GK, McAuliffe JJ, Miles L, Hughes EA, McCann JC, Harlow KE, Kurth CD, Williams MT, Vorhees CV, Danzer SC. The effects of neonatal isoflurane exposure in mice on brain cell viability, adult behavior, learning, and memory. Anesth Analg 2009; 108: 90-104.

7. Stratmann G, Sall JW, May LD, Bell JS, Magnusson KR, Rau V, Visrodia $K H$, Alvi RS, Ku B, Lee MT, Dai $R$. Isoflurane differentially affects neurogenesis and longterm neurocognitive function in 60-day-old and 7-day-old rats. Anesthesiology 2009; 110: 834-848.

8. Bercker S, Bert B, Bittigau P, Felderhoff-Muser U, Buhrer $C$, Ikonomidou $C$, Weise $M$, Kaisers UX, Kerner $T$. Neurodegeneration in newborn rats following propofol and sevoflurane anesthesia. Neurotox Res 2009; 16: 140-147.

9. Bittigau P, Sifringer M, Genz K, Reith E, Pospischil D, Govindarajalu S, Dzietko M, Pesditschek S, Mai I, Dikranian K, Olney JW, Ikonomidou C. Antiepileptic drugs and apoptotic neurodegeneration in the developing brain. Proc Natl Acad Sci USA 2002; 99: 15089-15094.

10. Huang J, Jing S, Chen X, Bao X, Du Z, Li H, Yang T, Fan $X$. Propofol administration during early postnatal life suppresses hippocampal neurogenesis. Mol Neurobiol 2015; 53: 1031-1044.

11. Hara M, Kai Y, Ikemoto Y. Propofol activates GABAA receptor-chloride ionophore complex in dissociated hippocampal pyramidal neurons of the rat. Anesthesiology 1993; 79: 781-788. 
12. Kochs E, Hoffman WE, Werner C, Thomas C, Albrecht $R F$, Schulte am Esch J. The effects of propofol on brain electrical activity, neurologic outcome, and neuronal damage following incomplete ischemia in rats. Anesthesiology 1992; 76: 245-252.

13. Hans P, Bonhomme V, Collette J, Albert A, Moonen G. Propofol protects cultured rat hippocampal neurons against $\quad \mathrm{N}$-methyl-D-aspartate receptor-mediated glutamate toxicity. J Neurosurg Anesthesiol 1994; 6: 249-253.

14. Daskalopoulos $R$, Korcok J, Farhangkhgoee $P$, Karmazyn M, Gelb AW, Wilson JX. Propofol protection of sodium-hydrogen exchange activity sustains glutamate uptake during oxidative stress. Anesth Analg 2001; 93: 1199-1204.

15. Grasshoff C, Gillessen T. The effect of propofol on increased superoxide concentration in cultured rat cerebrocortical neurons after stimulation of N-methyl-daspartate receptors. Anesth Analg 2002; 95: 920-922.

16. O'Shea SM, Wong LC, Harrison NL. Propofol increases agonist efficacy at the $\operatorname{GABA}(A)$ receptor. Brain Res 2000; 852: 344-348.

17. Yano $T$, Nakayama $R$, Ushijima K. Intracerebroventricular propofol is neuroprotective against transient global ischemia in rats: Extracellular glutamate level is not a major determinant. Brain Res 2000; 883: 69-76.

18. Dobbing J, Sands J. Comparative aspects of the brain growth spurt. Early Hum Dev 1979; 3: 79-83.

19. Olney JW, Farber NB, Wozniak DF, Jevtovic-Todorovic $V$, Ikonomidou C. Environmental agents that have the potential to trigger massive apoptotic neurodegeneration in the developing brain. Environ Health Perspect 2000; 108(S3): 383-388.

20. National Research Council (US) Committee for the update of the guide for the care and use of laboratory animals. Guide for the care and use of laboratory animals. 8th edition. Washington (DC): National Academies Press (US) 2011. http://www.ncbi.nlm.nih.gov/books/NBK54050/.

21. Vorhees CV, Williams MT. Morris Water Maze: Procedures for assessing spatial and related forms of learning and memory. Nat Protoc 2006; 1: 848-858.

22. Mishra SK, Kang JH, Lee CW, Oh SH, Ryu JS, Bae YS, Kim HM. Midazolam induces cellular apoptosis in human cancer cells and inhibits tumor growth in xenograft mice. Mol Cells 2013; 36: 219-226.

23. Wang $H$, Xue Z, Wang $Q$, Feng $X$, Shen Z. Propofol protects hepatic LO2 cells from hydrogen peroxideinduced apoptosis via activation of extracellular signalregulated kinases pathway Anesth Analg 2008; 107: 534-540.

24. Yang B, Liang G, Khojasteh S, Wu Z, Yang W, Joseph D, We $H$. Comparison of neurodegeneration and cognitive impairment in neonatal mice exposed to propofol or isoflurane. Plos One 2014; 9: e99171-179.

25. Yu D, Jiang Y, Gao J, Liu B, Chen P. Repeated exposure to propofol potentiates neuroapoptosis and long-term behavioral deficits in neonatal rats. Neurosci Lett 2013; 534: 41-46. 